\title{
SAPSUCKER DAMAGE IN COASTAL BRITISH COLUMBIA ${ }^{1}$ By WOLF G. ZILLER and DAVID STIRLING ?
}

During the "Hungry Thirties" Wolf G. Ziller worked as a skilled laborer for the Great Lakes Paper Company, Limited, Fort William, Ontario, from which he resigned after becoming Night Superintendent for the Sulphite Department. Resuming his academic training at the age of 32 he obtained his B. Sc. F. at the University of British Columbia (1949), and his M.A. and Ph.D. at the University of Toronto (1952 and 1955). He is now in charge of mycological identifications at the Forest Entomology and Pathology Laboratory, Victoria, B.C., specializing for over ten years in research on tree diseases caused by rust fungi.

David Stirling became interested in natural history at 12 years of age. Soon after leaving high school at Athabasca, Alberta, in 1939, he joined the army and was commissioned a first lieutenant at the Royal Military College, Sandhurst, in 1945. Since 1946 he has been employed in wildlife and forestry work. He has studied birds in Europe, Australia, New Zealand, and North America. He has been employed as a seasonal Forest Technician, Forest Entomology and Pathology Laboratory, Victoria, B.C.

\section{ABSTRACT}

The characteristics and feeding habits of the red-breasted sapsucker, Sphyrapicus varius ruber (Gmelin), are outlined. The bird appears to fluctuate violently in numbers. Incidental observations suggest that a large population of sapsuckers can cause considerable damage to forest trees.

\section{INTRODUCTION}

Although well known to ornithologists, little attention is paid to sapsuckers by foresters. The occasional damage caused by these handsome birds is normally insignificant, but instances are known where they have caused serious injury to forest and fruit trees alike; stain and decay develop around sapsucker punctures, reducing the commercial value of standing timber; and whole apple orchards have been destroyed by these birds (4).

\section{Identification \\ THE BIRD}

Except for its tongue which is especially adapted for its feeding habits, the sapsucker very much resembles the other woodpeckers; instead of the dartlike point that terminates the long tongue of the typical woodpecker, the sapsucker's tongue is short and tipped with a little brush (5). The red-breasted sapsucker, Sphyrapicus varius ruber (Gmelin), is the only species of sapsucker inhabiting the forests of coastal British Columbia. It measures from $8 \frac{1}{2}$ to 9 inches in length, its back and tail are black, checkered with white, the entire head and breast are bright red, and there is a conspicuous white blaze on the wing. Its call, a low whining mew, is a characteristic sound of the woods in

\footnotetext{
'Contribution No. 781 from the Forest Entomology and Pathology Branch, Department of Forestry, Ottawa, Canada.

'Forest Entomology and Pathology Laboratory, Victoria, B.C.
} 
spring and early summer. Its drumming, consisting of several quick taps followed by four more widely spaced taps, is distinctive. The female (Fig. 1), although not as brightly colored, closely resembles the male.

\section{Feeding Habits}

The bird selects the place to dig its sap-wells by means of test borings. These small circular punctures can be seen in rows around the limbs and trunks of trees. If the bark is the proper thickness and the sap flow is right the bird proceeds to enlarge the holes. These workings now take on a definite pattern; the holes are commonly arranged in rings around small limbs and partial circles on larger limbs and trunks. Vertically the punctures appear as neat, uniform rows (Fig. 2). In order to obtain a constant supply of fresh cambium and sap the holes are enlarged, and as the sap dries up in the old borings new ones are excavated directly below or on a neighboring tree. The sapsucker attacks only living trees.

Part of the sapsucker's diet consists of insects. In June and July sapsuckers can be seen catching large insects, such as flying ants, on the wing in the manner of a flycatcher, or eating insects that are attracted by sap exuding from bore holes. An analysis of 64 stomachs representing every month of the year revealed 40.7 per cent of vegetable food and 53.53 per cent insect food. Vegetable content was highest between October and April, while insects formed the bulk of the food during the summer months (2).

It has frequently been observed that certain trees or groups of trees are attacked while larger areas of surrounding woodland are devoid of sapsucker work. This can be explained by the territorial nature of the sapsucker during the breeding season and its normally sedentary habits throughout the year. Once a series of sap-wells has been dug the bird makes its rounds each day, gathering food, and protecting its "orchard" from thirsty squirrels, hummingbirds, warblers, and other sapsuckers.

\section{The DAMAge}

Sapsucker damage was first brought to the senior author's attention in the summer of 1952, during an investigation of basal scar damage in trees on the Queen Charlotte Islands. The damage had occurred to mature hemlock, Tsuga heterophylla (Raf.) Sarg., north of Mosquito Lake, Moresby Island, approximately 120 miles southwest of Prince Rupert. Data from two sample plots representing average conditions for the area on (a) a hill top and (b) a side hill are summarized in Table 1. Prevailing climate, stand history, and the complete absence of charred debris on the forest floor ruled out fire as a possible cause for any of the basal scars. From 15 to 53 per cent of the hemlock trees were found to be scarred; 25 to 66 per cent of these scarred trees bore punctures indicating that the scars were caused by sapsuckers. There were many "hidden" scars, the loose, punctured outer bark concealing the dead and blackened sapwood underneath. Most scars caused by sapsuckers occurred on the down-hill side of butts of living, mature hemlock, although some scars with punctures were observed as high as 20 feet above ground. The punctures served as courts of entry for a number of bacteria and fungi which killed the inner bark and cambium in the vicinity of the wounds, then stained the adjacent sapwood (Figs. 3-6), and produced the initial stages of butt rot which would 
ultimately result in the premature death of the tree by wind-throw. Much, if not most, of the damage, judged by the age of the callus tissue around the few punctures examined, seemed to have been done between 1949 and 1950.

TABLE 1

Sapsucker Damage to Western Hemlock on Two Sample Plots NoRTHWEST OF MOSQUito LaKe, MoRESBy IsLAND

\begin{tabular}{|c|c|c|c|c|c|c|}
\hline \multirow{2}{*}{$\begin{array}{l}\text { Plot } \\
\text { Bize, } \\
\text { acres }\end{array}$} & \multicolumn{2}{|c|}{$\begin{array}{c}\text { Range of DBH } \\
\text { inches }\end{array}$} & \multirow[b]{2}{*}{ Exposare } & \multicolumn{3}{|c|}{ Namber of Trees } \\
\hline & $\underset{\text { all }}{\text { trees }}$ & $\begin{array}{c}\text { scarred } \\
\text { trees }\end{array}$ & & total & $\begin{array}{l}\text { with } \\
\text { Bcars }\end{array}$ & $\begin{array}{l}\text { with panc- } \\
\text { tured sears }\end{array}$ \\
\hline $1 / 5$ & 2 to 76 & 4 to 50 & south & 79 & 12 & $8^{1}$ \\
\hline $3 / 10$ & 14 to 36 & 16 to 36 & flat & 30 & 16 & $4^{3}$ \\
\hline
\end{tabular}

${ }^{1}$ Punctured scars basal, facing downhill (south).

${ }^{3}$ Punctured scars not oriented in direction or position.

The red-breasted sapsucker's preference for the sap and inner bark of coniferous trees ensures it a constant supply of sustenance during the winter months when insects are not available. However, it has been postulated that large numbers of sapsuckers perish during exceptionally severe winters when the sap of coniferous trees freezes. This may account for the marked population fluctuations that have been observed. Guiguet (3) states that sapsuckers were very abundant on the Queen Charlotte Islands during the summers of 1946 and 1947, but not a single bird was seen during five weeks spent in this area during the summer of 1952. It is possible that the severe winter of 1949-1950 was responsible for the death of sapsuckers. At Massett, approximately 60 miles north of Mosquito Lake, the mean temperature in January, 1950 , was $23^{\circ} \mathrm{F}$. (1), $13^{\circ}$ lower than the average mean over the past 57 years and the lowest ever recorded. Temperatures of $0^{\circ} \mathrm{F}$. and lower were reported from several coastal points during the winter of 1949-1950. Sapsucker holes drilled at the base of large hemlocks on Moresby Island in 1950 indicate that the birds were attempting to find food by pecking through the thick bark near ground level where the cambium was not yet frozen, definitely an abnormal situation.

\section{Tree Hosts}

Sporadic local damage of minor significance attributed to the red-breasted sapsucker has been observed in recent years on Vancouver Island and the coastal mainland. On one alder tree the punctures seemed to have served as courts of entry for a fungus, Didymosphaeria oregonensis Goodding, that subsequently caused a canker girdling the main stem directly below the sapsucker punctures. Tops of Scots pine, 22 years old, in a plantation on northern Vancouver Island were girdled and killed from sapsucker injury. A few individual trees of western hemlock and amabilis fir (Figs. 1 and 2), approximately 30 years old, were found to be severely punctured and dying as a result. In nearly all cases, with the exception of the basal scar damage on Moresby Island, only one tree or a small group of trees was severely attacked, 
neighboring trees of the same species and approximately the same ange and physiological condition remaining unscathed. This confirms observations made by Pearson (4) over a period of 15 years.

Bent (2) states that 67 species of forest, fruit, and ornamental trees, and shrubs, are known to have been tapped by the red-breasted sapsucker. Specimens of the following tree species, collected in British Columbia west of the Coast Mountains and examined by one or both of the authors, showed signs of sapsucker damage: Abies amabilis (Dougl.) Forb. (amabilis fir), Acer macrophyllum Pursh (broadleaf maple), Alnus rubra Bong. (red alder), Amelanchier florida Lindl. (Pacific serviceberry), Betula papyrifera Marsh. (western white birch), Larix leptolepis (Sieb. \& Zucc.) Gord. (Japanese larch), Pinus contorta Dougl. (lodgepole pine), Pinus sylvestris L. (Scots pine), Populus tremuloides Michx. (trembling aspen), Pseudotsuga menziesii (Mirb.) Franco (Douglas fir), Salix spp. (willow), and Tsuga heterophylla (Raf.) Sarg. (western hemlock).

This report is intended only as a record of a number of incidental observations which confirm that the sapsucker, after a periodic build-up in population, can cause significant damage to conifers on the West Coast. It is not the outcome of intensive or extensive studies on the subject.

\section{ACKNOWLEDGMENT}

The authors wish to express their appreciation to Charles J. Guiguet, Curator of Mammalogy and Ornithology, Provincial Museum, Victoria, B.C., for technical information, the loan of the sapsucker specimen shown in Fig. 1, and a review of the manuscript.

\section{REFERENCES}

1. ANONYMOUS. 1951. Climate of British Columbia, report for 1950. Gonzales Observatory, Victoria, B.C., Canada Dept. of Transport.

2. BENT, A. C. 1939. Life histories of North American woodpeckers. U.S. Nat. Mus. Washington, D.C., Bull. 174:126-154.

3. GUIGUET, C. J. 1954. The birds of British Columbia. Prov. Mus. Handbook No. 6, Victoria, B.C.

4. PEARSON, T. G. 1933. Woodpeckers, friends of our forests. Nat. Geogr. Mag. 63 (4) : 453-479.

5. TAVERnER, P. A. 1934. Birds of Canada. Nat. Mus. Canada, Bull. No. 72, Ottawa.

\section{Captions for Figures 1-6 on page 335}

FIGURE 1. Female of red-breasted sapsucker feeding on a fre trunk. Note diagonal rows of test borings below its feet. $\times 1 / 4$.

FIGURE 2. Opposite side of the trunk shown in Fig. 1. Note vertical rows of "sap-wells". $\times 1 / 4$.

FIGURES 3-6. A chip from the butt of a living, mature hemlock tree near Mosquito Lake, Q.C.I., attacked by sapsuckers. $x$ 1/2. Fig. 3. Face view. Fig. 4. Side view, dark area showing dead inner bark and cambium ("hidden scar"). Fig. 5. Dark areas showing dead, discolored sapwood directly under the bark; light area showing 3 -year growth of healthy sapwood fringed by callus tissue. Fig. 6. Sapsucker holes perforating the section of bark which was removed in order to show Fig. 5. Note areas of living (light) and dead (dark) cambium, and phloem. 

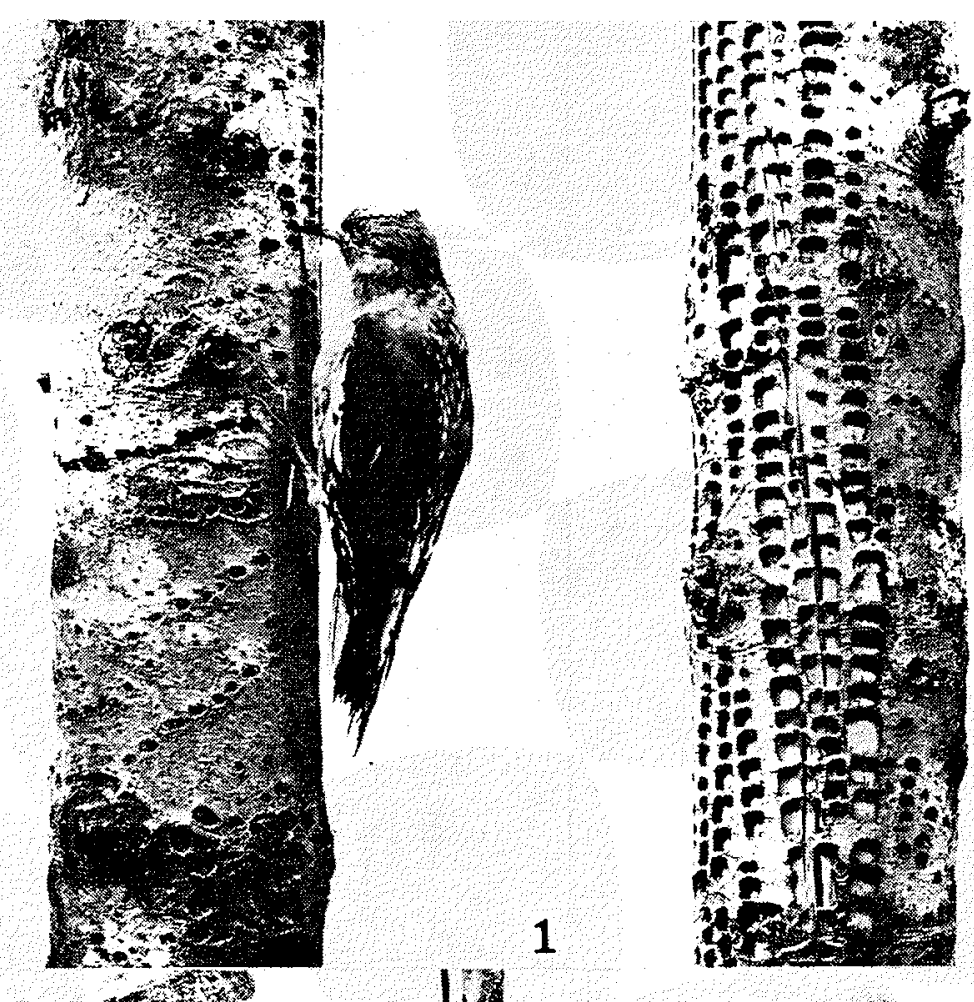

2
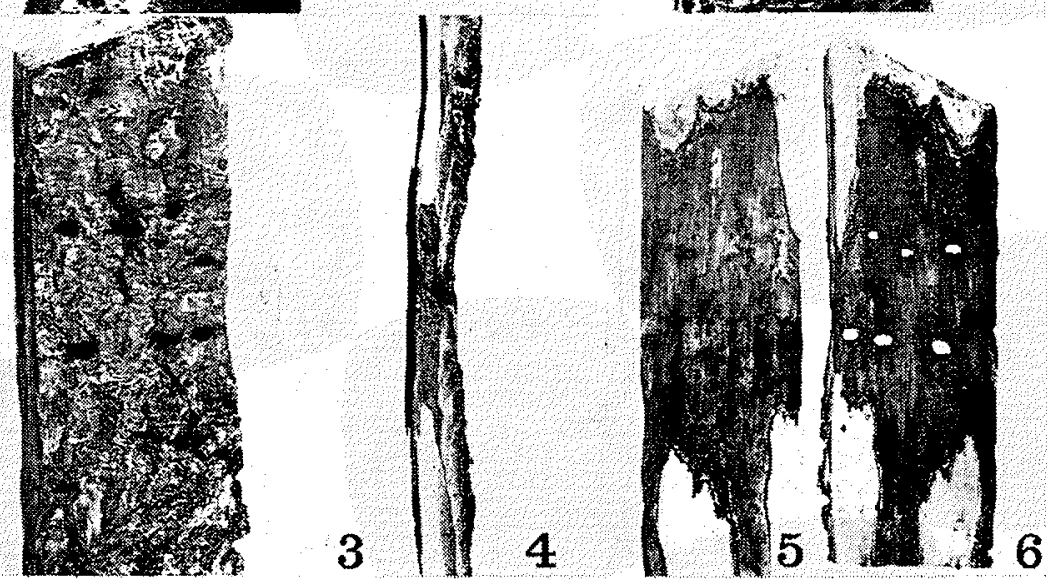

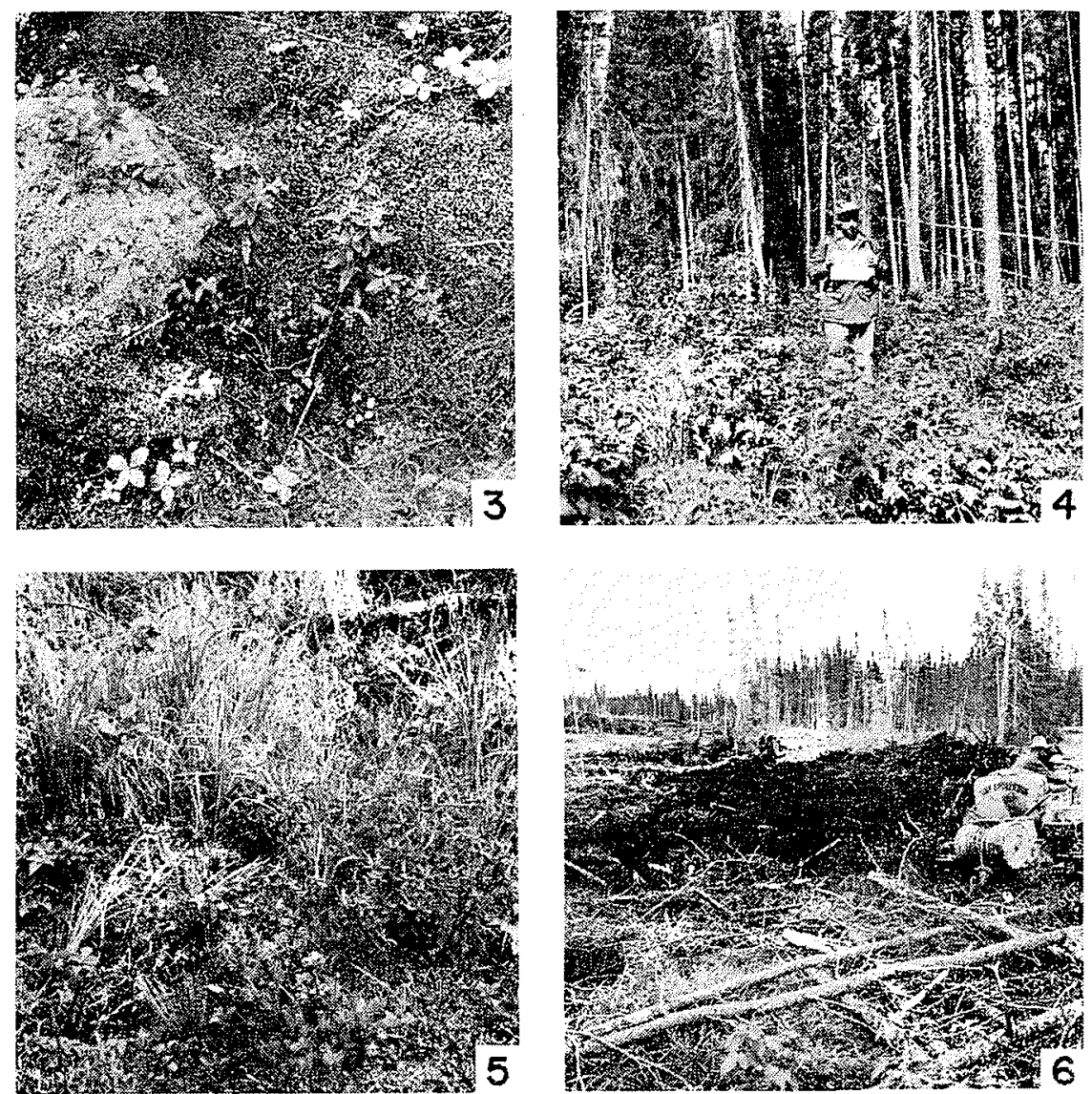

FIGURE 3. Feacher moss and sphagnum moss under a stand of black spruce.

FIGURE 4. Shrub-herb-grass communicy five years after cutting on a fresh sitc.

FIGURE 5. Grass-shrub community five years after cutting on a wet site; note black spruce regeneration in foreground.

FIGURE 6. Secdbed preparation on a fresh to moderatcly moist black spruce cut-over aren. 